\title{
Kemampuan Mahasiswa Calon Guru Dalam Mengembangkan Instrumen Tes Hasil Belajar Kategori Higher Order Thinking Skill
}

\author{
Nur Izzati ${ }^{1}$, Febrian $^{2 *}$ \\ ${ }^{1,2}$ Universitas Maritim Raja Ali Haji, Tanjungpinang, Provinsi Kepulauan Riau 29111 , Indonesia \\ Pengiriman: 23/Oktober/2020; Diterima: 25/Maret/2021; Publikasi: 31/Maret/2021 \\ DOI: https://doi.org/10.31629/jg.v6i1.2672
}

\begin{abstract}
Abstrak
Tujuan penelitian ini adalah untuk mengetahui kemampuan mahasiswa calon guru matematika dalam melakukan tahap-tahap pengembangan tes hasil belajar kategori Higher Order Thinking Skill (HOTS). Penelitian ini merupakan penelitian deskriptif. Subjek penelitian merupakan mahasiswa calon guru matematika yang mengikuti perkuliahan Evaluasi Pembelajaran Matematika. Data penelitian dikumpulkan melalui penugasan proyek. Data dinalisis disajikan secara deskriptif. Hasil penelitian menunjukkan bahwa kemampuan mahasiswa calon guru dalam mengembangkan instrumen tes kategori HOTS secara klasikal tergolong baik dengan perolehan nilai rata-rata sebesar 76,2. Kemampuan mahasiswa ini terbagi dalam tiga kategori, yaitu 32,1\% termasuk kategori sangat baik, 39,3\% tergolong baik, 25\% tergolong cukup baik dan 3,6\% termasuk kategori sangat kurang. Berdasarkan aspek kompetensi yang dinilai, rata-rata kemampuan mahasiswa tergolong baik. Pada aspek menganalisis butir soal, kemampuan mahasiswa tergolong cukup baik.
\end{abstract}

Kata kunci: mahasiswa calon guru; instrumen tes hasil belajar; HOTS

\begin{abstract}
The purpose of this study was to determine the ability of prospective mathematics teacher students to undertake the stages of developing a learning outcome test for the Higher Order Thinking Skill (HOTS) category. This research is descriptive research. The research subjects were prospective mathematics teacher students who attended the Mathematics Learning Evaluation course. Research data were collected through project assignments. Data were analyzed and presented descriptively. The results showed that the ability of prospective teacher students in developing the HOTS category test instrument was classically good with an average score of 76.2. The ability of these students is divided into three categories, namely $32.1 \%$ which is in the very good category, $39.3 \%$ is classified as good, $25 \%$ is classified as quite good and $3.6 \%$ is in the very poor category. Based on the assessed competency aspect, the average student's ability is classified as good. In the aspect of analyzing the items, the students' abilities were quite good.
\end{abstract}

Keywords: prospective teacher students; learning outcome test instrument; HOTS

*Penulis Korespondensi

Email Address: febrian@umrah.ac.id

Handphone : : +62 82170504899 


\section{JURNAL GANTANG. Maret 2021; VI(1): 75 - 82 \\ p-ISSN. 2503-0671 \\ e-ISSN. 2548-5547}

\section{Pendahuluan}

Kurikulum pendidikan sekolah di Indonesia yang ditetapkan oleh pemerintah, sedikitnya sudah mengalami 10 kali perubahan. Perubahan kurikulum ini didasari oleh kurang sesuainya kurikulum yang ada dengan perkembangan zaman. Di era sekarang yaitu abad ke-21, dunia telah mengalami perkembangan yang sangat pesat, baik di bidang ekonomi, transportasi, teknologi, informasi maupun di bidang lainnya. Perkembangan ini perlu diselaraskan dengan penguasaan keterampilan abad ke-21, yaitu keterampilan berpikir tingkat tinggi atau HOTS yang meliputi berpikir kritis, kreatif, inovatif dan pemecahan masalah serta terampil dalam berkomunikasi dan berkolaborasi.

Guru merupakan ujung tombak sebagai pelaksana perubahan kurikulum tersebut. Guru mengambil peran dalam menjalankan perubahan pada proses pembelajaran dan penilaian. Pada proses pembelajaran, peserta didik tidak lagi diberi tahu akan tetapi mereka mencari tahu dari berbagai sumber, memanfaatkan teknologi dan bekerja sama dalam menyelesaikan masalah. Perubahan proses pembelajaran tentunya berdampak pada perubahan pada penilaian hasil belajar. Instrumen tes yang digunakan untuk mengukur hasil belajar peserta didik tidak hanya sebatas mengukur pengetahuan saja, akan tetapi juga mengukur keterampilan berpikir tingkat tinggi (HOTS). Oleh karena itu, mau ataupun tidak, guru mesti mampu mengembangkan intsrumen tes dengan soal kategori HOTS.

Dari sejumlah penelurusan diperoleh bahwa guru mengalami kendala dalam mengembangkan instrumen tes kategori HOTS. Penelitian menunjukkan bahwa dalam menyusun sebuah soal kategori berpikir tingkat tinggi, beberapa guru masih belum berhasil. Soal yang masih masuk kategori penerapan, oleh beberapa guru sudah dianggap sebagai soal dengan kategori berpikir tingkat tinggi (Rahaju et.al, 2020). Persepsi yang didasari atas miskonsepsi mengenai HOTS ini tentunya akan berdampak pada pembuatan instrumen tes kategori HOTS. Hal ini tentu sangat mengkhawatirkan.
Mengingat situasi ini, maka perlu upaya agar permasalahan yang dihadapi ini tidak terjadi kedepannya dengan cara melihat subjek yang potensial dan perlu perhatian untuk dilakukan pembinaan agar pemahaman HOTS dan integrasinya dalam evaluasi pembelajaran dapat terbentuk. Salah satu subjek tersebut adalah mahasiswa calon guru yang dilahirkan oleh sejumlah Lembaga Pendidikan dan Tenaga Kependidikan (LPTK) salah satunya Fakultas Keguruan dan Ilmu Pendidikan.

Fakultas Keguruan dan Ilmu Pendidikan (FKIP) merupakan institusi yang mencetak caloncalon guru, salah satunya adalah calon guru matematika melalui program studi pendidikan matematika. Selama masa studi, mahasiswa calon guru matematika membekali diri dengan berbagai kompetensi melalui mata kuliah wajib dan pilihan, salah satunya adalah mata kuliah evaluasi pembelajaran matematika yang termasuk mata kuliah wajib. Melalui mata kuliah evaluasi pembelajaran matematika, mahasiswa calon guru matematika mendapatkan pengetahuan tentang penilaian hasil belajar. Sebagaimana dijelaskan di atas, bahwa sistem penilaian hasil belajar sesuai kurikulum 2013 tidak hanya mengukur pengetahuan tetapi juga mengukur keterampilan termasuk keterampilan berpikir tingkat tinggi (HOTS).

Dengan mepertimbangkan hasil penelitian serta peran LPTK dalam mempersiapkan calon guru, maka perlu dilakukan peninjauan terhadap mahasiswa calon guru terkait paling tidak dua hal. Pertama, kemampuan HOTS mahasiswa calon guru. Kedua, kemampuan mahasiswa calon guru dalam menyusun instrumen penilaian hasil belajar kategori HOTS. Sejumlah penelitian yang memberikan informasi mengenai kedua hal tersebut diantaranya Gradini (2018) yang menunjukkan bahwa kemampuan berpikir tingkat tinggi calon guru Matematika berada pada level menengah dan rendah. Hal ini tentunya memiliki pengaruh terhadap kemampuan mereka dalam mneyusun instrumen penilaian hasil belajar kategori HOTS. Paling tidak hal ini ditunjukan oleh penelitian Wijaya (2019) yang menunjukkan 
bahwa kemampuan mahasiswa dalam melakukan pengembangan soal dengan standar HOTS masih rendah dibandingkan dengan menyusun soal kategori LOTS. Kedua hasil ini memberikan informasi bahwa penggalian akan kemampuan mahasiswa calon guru dalam memahami HOTS serta menunjukkannya dalam pengembangan instrumen hasil belajar perlu selalu dilakukan.

Berdasarkan paparan di atas, peneliti tertarik untuk menelusuri lebih jauh tentang kesiapan mahasiswa calon guru khususnya bidang matematika dalam melakukan tugas mempersiapkan penilaian hasil belajar peserta didik, khususnya berorientasi HOTS melalui penelitian dengan judul "Kemampuan Mahasiswa Calon Guru Matematika dalam Mengembangkan Instrumen Tes Hasil Belajar Kategori Higher Order Thinking Skill". Penelitian ini juga dilatarbelakangi oleh hasil penelitian yang menginformasikan bahwa penelusuran lebih jauh memang harus terus dilakukan untuk mendapatkan gambaran yang lebih holistik. Penelitian tersebut menunjukan bahwa mahasiswa calon guru Matematika masih memerlukan pendampingan dalam menyusun tes Matematika HOTS karena hanya dapat membuat soal HOTS hingga level $\mathrm{C} 4$ atau menganalisis. Oleh karena itu perlu ada penelitan lebih lanjut atau pelatihan tentang penyusunan tes Matematika HOTS agar mereka memiliki kemampuan yang bagus dalam menyusun tes Matematika HOTS (Listiani, 2021).

Berdasarkan latar belakang masalah yang telah diuraikan di atas, maka tulisan ini akan menyuguhkan informasi yang memaparkan kemampuan mahasiswa calon guru matematika dalam mengembangkan instrumen tes hasil belajar Kategori HOTS.

\section{Metode Penelitian}

Penelitian ini tergolong jenis penelitian deskriptif, yaitu penelitian yang dimaksudkan untuk mendeskripsikan varibel-variabel yang diteliti. Dalam hal ini, variabel yang diteliti adalah kemampuan mahasiswa calon guru matematika dalam mengembangkan instrumen tes kategori
HOTS. Penelitian dilakukan di Fakultas Keguruan dan Ilmu Pendidikan Universitas Maritim Raja Ali Haji, Kota Tanjungpinang, Provinsi Kepulauan Riau pada bulan April Agustus 2020.

Subjek penelitian adalah mahasiswa yang mengikuti perkuliahan Evaluasi Pembelajaran Matematika di program Studi Pendidikan Matematika, Fakultas Keguruan dan Ilmu Pendidikan (FKIP) Universitas Maritim Raja Ali Haji pada semester genap tahun 2020 sebanyak satu rombongan belajar. Terdapat 28 mahasiwa subjek penelitian yang diteliti kemampuannya dalam mengembangkan instrument tes hasil belajar katgeori HOTS.

Untuk mendapatkan informasi mengenai kemampuan mahasiswa dalam menyusun instrumen tes hasil belajar kategori HOTS maka diberikan penugasan dengan teknik proyek. Subjek penelitian diberikan tugas tentang pengembangan instrumen tes hasil belajar dengan soal kategori HOTS melalui lembar penugasan yang memuat instruksi untuk menjelaskan tujuan pengembangan tes hasil belajar kategori HOTS, menganalisis Kompetensi Inti dan Kompetensi Dasar pada materi yang dipilih oleh subjek, penyusunan kisi-kisi dan pengembangan butir soal dan kunci jawaban.

Sesuai dengan penugasan yang digunakan, maka instrumen penelitian ini berupa lembar penilaian tugas pengembangan instrumen tes hasil belajar dengan soal kategori HOTS. Pengembangan lembar penilaian tugas mengacu pada aspek-aspek kompetensi yang diperlukan dalam mengembangkan suatu instrumen tes secara umum dan aspek kekhususan tentang pengembangan butir-butir soal kategori HOTS. Aspek-aspek tersebut terdiri dari: analisis level capaian Kompetensi Dasar (KD) dan turunan indikatornya yang dapat dibuatkan soal HOTS, pengembangan indikator soal HOTS, penyusunan kisi-kisi soal, pengembangan butir soal HOTS, dan analisis butir soal. Dari lima aspek ini, diturunkan menjadi 11 indikator dengan 27 butir penilaian seperti disajikan pada Tabel 1 . 


\section{JURNAL GANTANG. Maret 2021; VI(1): 75 - 82 \\ p-ISSN. 2503-0671 \\ e-ISSN. 2548-5547}

Tabel 1

Indikator penilaian kemampuan penyusunan instrumen tes hasil belajar kategori HOTS

\begin{tabular}{|c|c|}
\hline Aspek Penilaian & Butir Penilaian \\
\hline $\begin{array}{l}\text { Analisis level capaian Kompetensi } \\
\text { Dasar (KD) dan turunan } \\
\text { indikatornya yang dapat dibuatkan } \\
\text { soal HOTS }\end{array}$ & Ketepatan pemilihan KD dan turunan indikator pencapaian kompetensinya \\
\hline \multirow[t]{3}{*}{ Pengembangan Indikator Soal } & Ketepatan penggunaan kata kerja operasional \\
\hline & $\begin{array}{l}\text { Kelengkapan redaksi indikator soal, yaitu memuat unsur-unsur ABCD: } \\
\mathrm{A}=\text { audience (peserta didik) } \\
\mathrm{B}=\text { behaviour (perilaku yang harus ditampilkan) } \\
\mathrm{C}=\text { condition (kondisi yang diberikan) } \\
\mathrm{D}=\text { degree (tingkatan yang diharapkan) }\end{array}$ \\
\hline & Level kognitif yang ditagih minimal $\mathrm{C} 4$ \\
\hline Penyusunan kisi-kisi soal & Kelengkapan komponen kisi-kisi \\
\hline \multirow[t]{15}{*}{ Pengembangan butir soal HOTS } & Kesesuaian butir soal dengan KD dan IPK \\
\hline & Kesesuaian butir soal dengan indikator soal \\
\hline & $\begin{array}{l}\text { Materi yang ditanyakan, diukur dengan perilaku sesuai ranah kognitif Bloom pada } \\
\text { level menganalisis (C4), mengevaluasi (C5) dan mengkreasi/mencipta (C6) }\end{array}$ \\
\hline & Diawali dengan stimulus/kondisi yang logis \\
\hline & $\begin{array}{l}\text { Data yang disediakan memberikan informasi yang merujuk kepada pengetahuan atau } \\
\text { kemampuan dasar peserta didik }\end{array}$ \\
\hline & $\begin{array}{l}\text { Data yang diajukkan sebagai stimulus, sedapat mungkin dibuat dengan situasi yang } \\
\text { "autentik" atau nyata }\end{array}$ \\
\hline & $\begin{array}{l}\text { Tabel, gambar, grafik, peta, atau yang sejenisnya disajikan dengan jelas, terbaca, dan } \\
\text { berfungsi }\end{array}$ \\
\hline & $\begin{array}{l}\text { Butir soal memuat hanya satu kata kerja operasional untuk soal objektif dan satu atau } \\
\text { lebih kata kerja operasional untuk soal uraian }\end{array}$ \\
\hline & Menggunakan kata tanya/perintah yang menuntut jawaban terurai (khusus soal essay) \\
\hline & Pokok soal tidak memberikan petunjuk kunci jawaban (khusus soal objektif) \\
\hline & Pokok soal tidak memberikan pernyataan negatif ganda (objektif) \\
\hline & Hanya ada satu kunci jawaban yang tepat (khusus soal objektif) \\
\hline & Menggunakan bahasa yang sesuai dengan kaidah Bahasa Indonesia yang baku \\
\hline & Redaksi soal dirumuskan dengan jelas dan komunikatif \\
\hline & $\begin{array}{l}\text { Pilihan jawaban tidak menggunakan kelompok kata yang sama, kecuali merupakan } \\
\text { satu kesatuan pengertian (untuk soal objektif) }\end{array}$ \\
\hline \multirow[t]{5}{*}{ Analisis butir soal } & Langkah-langkah menganalisis butir soal \\
\hline & Tingkat kevalidan \\
\hline & Tingkat keajegan (reliabilitas \\
\hline & Variasi tingkat kesukaran \\
\hline & Kualitas Daya pembeda \\
\hline
\end{tabular}

Teknik analisa data penelitian menggunakan statistik deskriptif, yaitu statistik yang digunakan untuk menganalisis data dengan cara mendeskripsikan data sampel, seperti penggunaan diagram, nilai rata-rata, dan persentase. Data yang diperoleh melalui penilaian tugas proyek, ditabulasikan untuk memudahkan pengamatan. Tabulasi data dibuat berdasarkan keseluruhan aspek dan berdasarkan aspek-aspek yang diukur, serta berdasarkan kategori kualifikasi kompetensi mahasiswa dalam mengembeangkan instrumen tes kategori HOTS. Kategori kualifikasi kompetensi tersebut dikembangkan mengacu kepada kategori penilaian akademik Universitas Maritim Raja Ali Haji, sebagaimana disajikan pada Tabel 2.

Tabel 2

Klasifikasi kemampuan berdasarkan perolehan nilai

\begin{tabular}{cc}
\hline Nilai $(\mathrm{x})$ & Kategori \\
\hline $81 \leq \mathrm{x} \leq 100$ & Sangat Baik \\
\hline $71 \leq \mathrm{x}<81$ & Baik \\
\hline $61 \leq \mathrm{x}<71$ & Cukup Baik \\
\hline $51 \leq \mathrm{x}<61$ & Kurang \\
\hline $\mathrm{x}<51$ & Sangat Kurang \\
\hline
\end{tabular}

\section{Hasil dan Pembahasan}

Untuk memudahkan pengamatan dan analisis data, hasil penilaian tersebut dikelompok 
berdasarkan semua aspek penilaian, dan berdasarkan masing-masing aspek penilaian. Berikut ini deskripsi dari masing-masing kelompok data tersebut.

\section{Deskripsi Kemampuan Mahasiswa dalam Mengembangkan Instrumen Tes Kategori HOTS Berdasarkan Semua Aspek}

Ada lima aspek penilaian kompetensi mahasiswa calon guru dalam mengembangkan instrumen tes kategori HOTS. Kompetensi ini dirumuskan berdasarkan kompetensi yang diperlukan dalam mengembangkan suatu instrumen tes secara umum dan aspek kekhususan tentang pengembangan butir-butir soal kategori HOTS. Aspek-aspek tersebut terdiri dari: kemampuan mahasiswa menganalisis level capaian Kompetensi Dasar (KD) dan turunan indikatornya yang dapat dibuatkan soal kategori HOTS, pengembangan indikator soal HOTS, menyusunan kisi-kisi soal, mengembangkan butir soal HOTS, dan melakukan analisis butir soal. Berdasarkan semua aspek yang dinilai, diperoleh nilai rata-rata kemampuan mahasiswa dalam mengembangkan instrumen tes kategori HOTS sebesar 76,2. Merujuk kepada klasifikasi kompetensi pada Tabel 2, capaian ini termasuk kategori baik.

Selanjutnya, ditinjau dari masing-masing individu, persentase terbesar kemampuan mahasiswa dalam mengembangkan instrumen tes kategori HOTS berada pada kategori Baik, yaitu sebesar 39,3\%. Kemudian kategori sangat baik pada urutan kedua, yaitu sebesar $32,1 \%$. Dengan demikian, bisa dikatakan bahwa $71,4 \%$ mahasiswa atau sebanyak 20 orang dari 28 orang mahasiswa telah mampu mengembangkan instrumen tes kategori HOTS dengan baik dan bahkan sangat baik. Meskipun demikian, masih ada seorang mahasiswa yang berada pada kategori sangat kurang. Secara lengkap distribusi mahasiswa berdasarkan kategori kemampuan mengembangkan instrumen tes kategori HOTS disajikan pada Tabel 3.
Tabel 3

Distribusi Mahasiswa Berdasarkan Kategori Kemampuan Mengembangkan Instrumen Tes Kategori HOTs

\begin{tabular}{lcc}
\hline \multicolumn{1}{c}{ Kategori } & Jumlah & Persentase \\
\hline Sangat Baik & 9 & $32,1 \%$ \\
\hline Baik & 11 & $39,3 \%$ \\
\hline Cukup Baik & 7 & $25,0 \%$ \\
\hline Kurang & 0 & $0,0 \%$ \\
\hline Sangat Kurang & 1 & $3,6 \%$ \\
\hline
\end{tabular}

Deskripsi Kemampuan Mahasiswa dalam Mengembangkan Instrumen Tes Kategori HOTs Berdasarkan Aspek

Aspek pertama adalah analisis level capaian Kompetensi Dasar (KD) dan turunan indikatornya yang dapat dibuatkan soal kategori HOTS. Dalam mengembangkan soal kategori HOTS, penguasaan aspek ini sangatlah penting, karena tidak semua KD dapat dibuatkan soal HOTS. Capaian KD yang dapat dibuatkan soal HOTS berada level Analisis (C4), evaluasi (C5) dan kreasi/mencipta (C6) yaitu mencipatakan jawaban yang orisinal. Pilihan KD yang tidak tepat tentunya akan menyulitkan mahasiswa dalam mengembangkan soal pada level C4, C5 dan C6. Karena itu, diperlukan kemampuan melakukan analisis capaian $\mathrm{KD}$ dan turunan indikatornya yang dapat dibuatkan soal kategori HOTS. Secara klasikal, diperoleh nilai rata-rata pada aspek ini sebesar 72,3, yaitu termasuk kategori baik.

Aspek kedua adalah pengembangan indikator soal yang akan menjadi pedoman dalam mengembangkan butir-butir soal. Indikator soal dirumuskan menggunakan kata kerja operasional yang dapat diamati dan ukur. Perumusan indikator soal yang lengkap memuat unsur-unsur $\mathrm{ABCD}$, yaitu $\mathrm{A}=$ Audience (peserta didik), $\mathrm{B}=$ Behaviour (perilaku yang harus ditampilkan), $\mathrm{C}=$ Condition (kondisi yang diberikan), dan $\mathrm{D}=$ Degree (tingkatan yang diharapkan). Kemampuan mahasiswa dalam mengembangkan indikator soal termasuk kategori cukup baik dengan perolehan nilai rata-rata sebesar 70,2. 


\section{JURNAL GANTANG. Maret 2021; VI(1): 75 - 82 \\ p-ISSN. 2503-0671 \\ e-ISSN. 2548-5547}

Aspek ketiga adalah penyusunan kisi-kisi soal, di mana kisi-kisi ini menjadi pedoman pedoman dalam penyusunan dan perakitan soal. Kisi-kisi soal disajikan dalam bentuk matriks yang memuat kompetnsi dasar, indikator pencapaian kompetensi, materi pokok, indikator soal, level kogniti, bentuk tes, dan nomor soal. Penilaian dilakukan terhadap ketepatan dan kelengkapan komponen kisi-kisi. Kemampuan mahasiswa dalam menyusun kisi-kisi ini tergolong baik dengan nilai rata-rata 79,5.

Aspek ke-empat yaitu pengembangan butir soal HOTS. Mengembangkan butir soal HOTS berpedoman kepada kisi-kisi yang telah disusun. Butir-butir pertanyaan ditulis sesuai dengan kaidah penulisan butir soal HOTS. Kaidah penulisan butir soal HOTS, agak berbeda dengan kaidah penulisan butir soal pada umumnya. Perbedaannya terletak pada sub aspek materi, sedangkan pada sub aspek konstruksi dan bahasa relatif sama. Di mana materi yang ditanyakan, diukur dengan perilaku sesuai ranah kognitif Bloom pada level menganalisis (C4), mengevaluasi (C5) dan mengkreasi/mencipta (C6). Soal yang dikembangkan terdiri dari lima butir soal objektif dan lima butir soal esai. Penilaian dilakukan terhadap ketepatan penerapan kaidah penulisan butir soal HOTS, yaitu teridiri dari sub aspek materi, sub aspek konstruksi dan sub aspek bahasa yang terdiri dari 16 butir penilaian untuk soal objektif dan 10 butir penilaian untuk soal esai. Hasil penilaiannya menunjukkan bahwa kemampuan mahasiswa dalam mengembangkan butir-butir soal kategori HOTS tergolong baik dengan perolehan nilai ratarata sebesar 79,9. Namun, jika ditinjau dari kemampuan mahasiswa dalam mengembangkan soal kategori HOTS bentuk objektif dan esai terdapat perbedaan, di mana kemampuan mahasiswa dalam mengembangkan soal kategori HOTS dalam bentuk objektif tergolong sangat baik dengan perolehan nilai rata-rata sebesar 85,8 dan kemampuan mahasiswa dalam mengembangkan soal kategori HOTS bentuk esai tergolong cukup baik dengan perolehan nilai ratarata sebesar 70,5.
Aspek kelima yaitu analisis butir soal. Rangkaian kegiatan pada analisis butir soal adalah melakukan uji validitas butir soal, menguji reliabilitas instrumen, menghitung daya beda dan tingkat kesukaran butir soal. Pada penelitian ini yang dinilai adalah ketepatan dalam melakukan setiap tahapan analisis butir soal. Kemampuan mahasiswa calon guru dalam melakukan analisis butir soal masih tergolong cukup baik dengan perolehan nilai rata-rata sebesar 62,4. Untuk memudahkan pembacaan data, kemampuan mahasisiwa calon guru dalam mengembangkan instrumen kategori HOTS berdasar aspek ditinjau dari seluruh sampel disajikan pada Tabel 3.

Tabel 3

Kemampuan mahasiswa calon guru dalam mengembangkan instrumen kategori HOTS berdasar aspek ditinjau dari seluruh subjek

\begin{tabular}{|c|c|c|}
\hline Aspek Kompetensi & Nilai & Kategori \\
\hline $\begin{array}{l}\text { Analisis level capaian } \\
\text { KD dan turunan } \\
\text { indikatornya yang dapat } \\
\text { dibuatkan soal HOTS }\end{array}$ & 72,3 & Baik \\
\hline $\begin{array}{l}\text { Pengembangan } \\
\text { Indikator Soal HOTS }\end{array}$ & 73,8 & Baik \\
\hline $\begin{array}{l}\text { Penyusunan Kisi-Kisi } \\
\text { Soal }\end{array}$ & 79,5 & Baik \\
\hline $\begin{array}{l}\text { Pengembangan butir } \\
\text { soal HOTS }\end{array}$ & 79,9 & Baik \\
\hline Analisis butir soal & 62,4 & Cukup Bai \\
\hline
\end{tabular}

Hasil penelitian terkait kemampuan mahasiswa calon guru dalam hal penyusunan instrumen tes hasil belajar kategori HOTS ini kiranya sedikit berbeda dengan hasil penelitian terdahulu dimana kecenderungan mahasiswa hanya bisa menyusun butri soal hingga kemampuan $\mathrm{C} 4$ atau menganalisis (Listiani, 2021). Hal ini menandakan bahwa kemampuan dalam penyusunan instrumen hasil belajar kategori HOTS dapat berbeda antar satu subjek dengan subjek lainnya. Tentu dengan penelusuran lebih lanjut didapatkan apa sekiranya faktor yang melatarbelakangi hal tersebut.

Dalam penelitian ini, kemampuan mahasiswa calon guru dalam menyusun instrumen tes hasil belajar kategori HOTS 
termasuk dalam kategori yang baik. Dengan demikian, dapat dikatakan subjek penelitian telah memiliki kemampuan yang layak untuk menyusun instrumen tes hasil belajar kategori HOTS dan dapat menjadi salah satu modal yang baik untuk menjadi guru Matematika.

\section{Kesimpulan}

Berdasarkan hasil dan pembahasan dapat disimpulkan bahwa kemampuan mahasiswa calon guru dalam mengembangkan instrumen tes kategori HOTS secara kalsikal tergolong baik. Berdasarkan aspek kompetensi yang dinilai, rata-rata kemampuan mahasiswa tergolong baik. Sedangkan pada aspek menganalisis butir soal, kemampuan mahasiswa masih tergolong cukup baik.

\section{Ucapan Terimakasih}

Artikel ini merupakan publikasi hasil penelitian yang didanai oleh hibah internal Universitas Maritim Raja Ali Haji (UMRAH) dengan skema Penelitian Unggulan Perguruan Tinggi (PUPT). Oleh karena itu, kami mengucapkan terimakasih kepada institusi UMRAH atas dukungan tersebut.

\section{Referensi}

Arifin, Zainal. (2011). Evaluasi Pembelajaran. Bandung: PT Remaja Rosdakarya.

Ayuningtyas, N. \& Rahaju, E. B. (2013). Proses penyelesaian soal higher order thinking materi aljabar siswa SMP ditinjau berdasarkan kemampuan matematika siswa". Jurnal Ilmiah Pendidikan Matematika. 3. (1). 1-9.

Budiman, A. \& Jailani. (2014). Pengembangan instrumen asesmen higher order thinking skill (HOTs) pada mata pelajaran matematika SMP kelas VIII semester 1. Jurnal Riset Pendidikan Matematika, 1(2), hal. 139 - 151.

Ega, G., Firmansyah, B., \& Julia, N. (2018). Calon guru matematika melalui level hots marzano. EduMa, 7(2), 41-48.
Harahap, S.S. (2009). Analisis kritis terhadap laporan keuangan. Jakarta: Raja Grafindo Persada.

Jailani, \& Sugiman. (2018). Desain pembelajaran matematika untuk melatih higher order thinking skill (pertama). Yogyakarta: UNY Press.

Kemendikbud. (2018). Buku pegangan pembelajaran HOTs. Jakarta : Diraktorat Guru dan Tenaga Kependidikan.

Kemdikbud. (2017). Panduan penilaian HOTs. Jakarta: Diraktorat Guru dan Tenaga Kependidikan.

Kemdikbud. (2014). Konsep dan implementasi kurikulum 2013. Paparan Wamen Pendikbud RI Bidang Pendidikan.

Listiani, W., \& Sulistyorini, Y. (2021). Kompetensi pedagogik mahasiswa program studi pendidikan matematika dalam menyusun tes matematika HOTS. Laplace: Jurnal Pendidikan Matematika, 4(1), 99106.

https://doi.org/10.31537/laplace.v4i1.467

Rahaju, E. B., Dini, K., Fardah, P., \& Wijayanti, I. (2020). E B Rahaju, D K Fardah, P Wijayanti, I. (2020). Kemampuan guru-guru matematika SMP Kabupaten Ponorogo dalam mengembangkan soal berpikir tingkat tinggi. Jurnal Pendidikan Matematika Raflesia, 05(01), 75-81. Retrieved from https://ejournal.unib.ac.id/index.php/jpmr

Rosnawati. (2009). Enam tahapan aktivitas dalam pembelajaran matematika untuk mendayagunakan kemampuan berpikir tingtkat tinggi siswa. Prosiding Seminar nasional Revitalisasi MIPA dan Pendidikan MIPA. UNY: Yogyakarta.

Sumaryanta. (2018). Penilaian HOTs dalam pembelajaran matematika. Indonesian Digital Journal of Mathematics and Education, 8(8), hal. 500-509.

Saputra, Hatta. (2016). Pengembangan Mutu Pendidikan Menuju Era Global: Penguatan Mutu Pembelajaran dengan Penerapan HOTs (High Order Thinking Skills). Bandung: SMILE's Publishing. 
JURNAL GANTANG. Maret 2021; VI(1): 75 - 82

p-ISSN. 2503-0671

e-ISSN. 2548-5547

Wijaya, W., \& Andy, P. (2019). Profil

Kemampuan mahasiswa dalam mengembangkan instrumen tes mengacu standar hots pada mata kuliah evaluasi dan teknik pencapaian hasil belajar. Journal of Chemical Information and Modeling, 53(9), 1689-1699. 